\title{
Kovács István: TEÁOR 9604, avagy a prostitúció legalitásának gazdasági kritériuma
}

\begin{abstract}
Absztrakt
A magyar jogrendszer a prostitúció gyakorlásával szemben három kritériumot támaszt: közegészségügyi, közrendvédelmi és gazdasági megfeleltetés. A tanulmány a gazdasági kritériumot veszi górcső alá, és vizsgálja annak lehetöségét, hogy az a gyakorlatban a prostituáltak oldaláról kivitelezhetö-e, illetve a hatóságok azt akár kényszer útján képesek-e behajtani.
\end{abstract}

\section{Abstract}

Three criteria of the practice of prostitution are raised by the Hungarian law system: public health, public order and economic criteria. The economic criteria is examined by the study, and it will be tested, that the prostitutes are able to pay tax after the job or not, and the the authorities are able to encash it (by force) or not.

$* * *$

\section{Bevezetés}

A romantikus sztereotípiák és ábrándok ellenére, miszerint a prostitúció egy milliárdos üzletág nem sok prostituáltat látunk luxuskörülmények között élni, vagy olyan jövőképpel rendelkezni, amelyben a szexmunkások átlag feletti életszínvonal elérésére lehetnének képesek. De akkor joggal vetődik fel a kérdés -, amely nyilvánvalóan csupán költői -: hová kerül a vagyon, hová centralizálódik a bevétel?

2015-ben egy statisztikai jelentés szerint csak Spanyolországban 26,8-, Japánban 24-, Amerikában 14,6-, a világon pedig 186 milliárd dollár bevételre tettek szert a prostitúciós holdudvarok. (Holdudvar alatt az illegális bevételből profitáló, leginkább a szervezett bünözői körökhöz köthető csoportokat, személyeket értem. Akár a szexmunkásokat közvetítő, akár a prostituáltakat futtató személyek.) ${ }^{301}$, ${ }^{302}$ Németországban e bevételek 18 milliárd dollárra nőttek, azonban köszönhetően a legális bordélyrendszernek, abból az állam is részint, de profitált. (Hollandiában szintén, ahol 800 millió dollár profitot termelt a prostitúciós üzlet.) A listát közel 73 milliárd dollárral a gazdaságilag, és katonailag is leginkább feltörekvő ázsiai ország, Kína vezeti. ${ }^{303}$ Magyarország vonatkozásában sem a Havoscope jelentés, sem pedig más statisztikai adatbázis egzakt eredményeket nem közölt, feltételezve ezzel, hogy az vagy becslésen

\footnotetext{
${ }^{301}$ KovÁCS István: A szervezett bünözés két alappillére: az emberkereskedelemhez kapcsolódó prostitúciós büncselekmények valamint a kábítószer-kereskedelem összefonódása. Nemzetbiztonsági Szemle, 2014., II. évfolyam 4. szám, pp. 79-101.

${ }^{302}$ KovÁCS István: Magyarország határain átnyúló szervezett bünözés és prostitúciós büncselekmények a schengeni térségben, különös tekintettel a SOCTA és EUROSTAT értékelésére. Határrendészeti Tanulmányok, 2017/e/4. szám, pp. 82-161.

303 Havoscope: Prostitution: Prices and Statistics of the Global Sex Trade. Forrás: https://www.amazon.com/dp/B00ZZBFXO2/ref=rdr_kindle_ext tmb (A letöltés dátuma: 2017.04.17.)
} 
alapul, vagy ezzel kapcsolatos adat még becslés szintjén sem, azaz egyáltalán nem áll rendelkezésre.

Annak ellenére, hogy a Központi Statisztikai Hivatal (a továbbiakban KSH) felmérése szerint a prostitúció gyakorlása a legkevésbé hasznos, a legevesebb hatalommal bíró, és a legalacsonyabb presztízsü szakmák egyike, a társadalom által károsnak ítélt, a deviancia perifériáján mozgó szexmunka mégis a kereseti megítélés szempontjából a legmagasabb jövedelmü foglalkozások közé került besorolásra. (A kérdés, miszerint ebböl ma Magyarországon ki profitál, ugyan csak költői marad.) (Ugyan ilyen megítélés alá esett a pornóipar is.) ${ }^{304}$ Megjegyzendő továbbá, hogy némiképp ellentmondásosak azon megállapítások, hogy a prostitúció a legkevesebb hatalommal bíró foglalkozások egyike volna, hiszen ez utóbbinak ellenkezőjét számos, a közelmúltban is megjelent tanulmány cáfolja. ${ }^{305}$ Továbbá, ha ez a foglalkozás olyannyira haszontalan lenne, mint, ahogy azt a válaszadók állítják, miért mutatható ki, hogy Izraelben például havi rendszerességgel több, mint tízezer-, Dániában pedig több, mint kétszázezer férfi vesz igénybe szexuális szolgáltatást?! Az Amerikai Egyesült Államokban 2012-ben a férfiak 9,1 százaléka vallotta, hogy fizetett már szexuális szolgáltatásért, ugyancsak nem haszontalan indokokra visszavezethetően. Szót nem ejtve arról, hogy felnőtt filmek szereplöit - sztereotíp, és elöítélettel tarkított módon miért sorolják a prostituáltakkal egy kalap alá, annak ellenére, hogy a két szakma teljesen más attitüdökre, szabályokra és szakmai kompetenciákra összpontosít. ${ }^{306}$

Mindez azért bír kiemelt jelentőséggel, mert az illegális tevékenységek becslése a 2000-es évtől kezdődően a GDP számítások részévé vált. (A tanulmány is e időszakot veszi górcső alá, vagyis mi volt a kiindulópont a GDP módosításának tárgyában.)

Az Eurostat javaslata alapján az illegális tevékenységek három részterületére (prostitúció, drogkereskedelem, csempészet) kell a KSH-nak becsléseket készíteni. E három részterület közül a KSH a prostitúcióra és a drogkereskedelemre készít becsléseket, mert ezek rövidtávon nem változnak jelentősen, és megfelelö mennyiségü információ áll róluk rendelkezésre. (A csempészettel kapcsolatban a helyzet eltérő. Annak ellenére, hogy itt is vannak állandó elemek, itt egy olyan tevékenységről van szó, ami azonnal alkalmazkodik a piac és a törvényi szabályozás változásaihoz, de ezek nem mérhetők statisztikai értelemben.) Az illegális tevékenységekkel kapcsolatos termelési, fogyasztási és jövedelmi becslések 2006-ban kerültek bevezetésre a Nemzeti Számlák rendszerébe. ${ }^{307}$ Magyarországon az illegális gazdasági tevékenységek mintegy 0,8 százalékkal emelik meg a GDP-t, ami az Európai Uniós átlaghoz viszonyítva is elég magas értéket képvisel.

Hol húzódik az a határvonal, ahol a prostituált magatartása -, a holdudvar kizsákmányoló és élősdi cselekményeivel egyetemben - illegálissá válik, valamint az abból származó profit és bevétel a feketegazdaságot erősíti? A tanulmány e kérdésekre keres oly módon választ, hogy a prostitúció (gazdasági) jogi szabályozását forráskritika, analízis és szintézis tudományos módszerek felhasználásával - górcső alá

\footnotetext{
${ }^{304}$ JANÁK Katalin: Mikrocenzus 2016. A foglalkozások presztízse. Budapest, Központi Statisztikai Hivatal, 2018.

${ }^{305}$ KovÁCS István: Is the prostitution a threat/danger to a country's (national)security? Nemzetbiztonsági Szemle, 2017/d/Special Issue, 1-24.o. 2017/d, pp. 1-24.

${ }^{306}$ KovÁCS István: Pornográfia, vagy prostitúció, esetleg mindkettő? Hadtudományi Szemle, $2017 / \mathrm{f} / 4$. szám, pp. 449-484.

307 GNI Inventory: Budapest, Központi Statisztikai Hivatal, $2009 . \quad$ Forrás: https://www.ksh.hu/docs/hun/xftp/modsz/gni_inventory_ver2.1hun.pdf) (A letöltés ideje: 2019.03.26.)
} 
veszi, a hatóságok munkáját elemzi és értékeli, majd a prostitúció jelenség kezelésére paradigmaváltás reményével megoldási alternatívákat javasol.

\section{A prostitúció hazai szabályozása napjainkban}

A tanulmány formai keretei nem teszik lehetővé, hogy a prostitúció magyarországi szabályozásáról részleteibe menően értekezzek, azonban annak lényegi elemeiről -, különös tekintettel a címből már sejtetni engedő gazdasági kritériumairól szólnom szükséges. (Három korábbi tanulmányom a szabálysértési törvényt ${ }^{308}$, a Büntető Törvénykönyvet ${ }^{309}$, valamint a prostitúció kezelésére szolgáló ORFK utasítást $^{310}$ is részleteiben elemzi, vizsgálva azok az 1950-ben elfogadott New Yorki egyezménnyel való korrelációját.)

Ma hazánkban a prostitúció, a törvényi szabályozásban elöírt kritériumok megtartása mellett legálisan gyakorolható tevékenység. A nemzetközi szabályozás, az 1950-ben született New Yorki Egyezmény a hazai jogalkotást nagyban befolyásolta. Ennek eredményeképpen a magyar Büntetö Törvénykönyv (2012. évi C. törvény) bizonyos futtatói magatartásokat büntetni rendel (például kerítés, kitartottság, stb.) és eleget téve az egyezmény rendelkezéseinek tiltja a bordélyházak létesítését. A szabálysértésekről szóló törvény (2012. évi II. törvény) pedig akkor értékeli a prostituált magatartását büntetendőnek, amennyiben a törvény által meghatározott keretfeltételeket részben-, vagy egyáltalán nem teljesíti. E feltételrendszer három kritérium köré épül fel: közegészségügyi-, közrendvédelmi- és gazdasági megfeleltetés. (A jogi anomália alapját e feltételrendszer keletkezteti, hiszen az egyezmény elismeri a prostituáltak áldozati jellegét, amit a törvény a kritériumok nem teljesítése esetén büntethetőséggel fenyeget, ad absurdum a prostituáltat bünelkövetőnek aposztrofálja. Az erről készült szabálysértési nyilvántartási rendszer pedig stigmát képez.) Az ORFK utasítás - parallel a jogi környezettel - pedig nem segíti elő a reintegrációs folyamatokat, és nem támogatja a prostituáltak társadalomba való visszailleszkedését, amelyet a bilateriális egyezmény követelményként határoz meg. Az elkövetkezendőkben ismerjük meg a három törvényi kitételt.

A közegészségügyi megfeleltetés elöírja a prostituáltak számára, hogy a munkavégzéshez szükséges egészségügyi igazolással („kiskönyvvel”) rendelkezzenek, amely tanúsítja, hogy fertőző betegségben nem szenvednek. Társadalmi érdek füződik ahhoz, hogy a szexuális vágy felkeltésére, illetve annak kielégítésére irányuló szolgáltatás a külvilágban betegségmentesen, a fertőzés kockázatának legkisebb valószínűségével realizálódhasson. (A szürővizsgálatok elvégzése egyoldalú, éles kritika érheti a jogalkotót a tekintetben, hogy az egyenlö bánásmód, mint alapvető jog gyakorlása a prostituáltakat ilyen feltételek mellett megilleti-e? Ad absurdum a prostituált szolgáltatásait igénybe vevő felet ${ }^{311}$ a jogszabály miért nem kötelezi arra, hogy igazolja, hogy fertőző betegségben nem szenved, és nem továbbítja azt közvetlenül, és közvetett módon a szolgáltatásban érintett további személyekre?!

\footnotetext{
${ }^{308}$ KovÁCS István: Jogharmonicázió vagy sem? Harmadik rész: a New Yorki Egyezmény és a 13/2014. (V.16) ORFK utasitás. Belügyi Szemle, 2017/c/10. szám, pp. 42-59.

${ }^{309}$ KovÁCs István: Jogharmonicázió vagy sem? Első rész: a New Yorki Egyezmény és a 2012. évi C. törvény - a Büntetö Törvénykönyv -. Jogelméleti Szemle, 2017/a/2. szám, pp. 88-106.

${ }^{310}$ KovÁcs István: Jogharmonicázió vagy sem? Második rész: a New Yorki Egyezmény, valamint a 2012. évi II.-, és a 1999. évi LXXV. törvény. Acta Humana, 2017/b/5. szám, pp. 41-58.

${ }^{311}$ KovÁCs István: A prostitúció jelensége és társadalmi kontrolljának vizsgálata empirikus módszerekkel. PhD értekezés, Budapest, UNI-NKE, 2016.
} 
Ugyanakkor ezzel kapcsolatban megjegyzendő, hogy az Alkotmánybíróság 2011-ben az egészségügyi kiskönyv bizonyos a prostituáltakra vonatkozó stigmatizáló, közvetlen rendelkezéseit megsemmisítette, biztosítva az emberi méltóság, mint abszolút alapjog érvényesülését.) $)^{312}$

A közrendvédelmi megfeleltetés két egymással összefüggő, konjuktív követelményt ír elö: védett övezeten kívüli felajánlkozás, valamint annak zaklatás mentes módja. Türelmi zónának nevezi a törvény a közterületnek azon részét, amelyet az önkormányzat a prostitúció tömeges megjelenése esetén rendelet útján kijelöl. (Tömeges megjelenés alatt a prostituáltak folyamatos vagy idényjellegü nagyobb számú, egyidejü területi koncentrálódását értjük, amely alkalmas a település nyugalmának megzavarására.) A prostituált e területen belül további szabályok megtartásával szexuális szolgáltatásra felajánlkozhat vagy a szexuális szolgáltatására irányuló kezdeményezést elfogadhatja. A törvény viszont a szexuális szolgáltatás zaklató jellegü felajánlását tiltani rendeli: zaklató jellegü a felajánlkozás, ha az más személy mozgását, illetve a más személy által vezetett jármű elindulásának mozgását megakadályozza, megzavarja, illetőleg zaklatásnak minősül ugyancsak a szóbeli felhívás agresszív, szeméremsértő, vagy erre utaló volta is. (Nem felejthetjük el, hogy e posztulátum nem csak a prostituáltakkal szemben ró kötelmeket, hanem az önkormányzatok, és a hatóságok részére is feladatokat határoz meg. Hogyan várjuk el a prostituálttól a jogkövető magatartást, ha például a fővárosi önkormányzat a munkavégzés helyszínéül türelmi zónát kijelölni nem kíván, vagy nem is tud?! ${ }^{313}$ )

A gazdasági szabályok betartása egyéni vállalkozói igazolvány meglétét és rendszeres jövedelemadó megfizetését feltételezi. Tekintettel arra, hogy az egyéni vállalkozóról és az egyéni cégről szóló törvény alapján a prostituáltak tevékenysége szolgáltatás jogcímén gyakorolható, valamint a személyi jövedelemadóról szóló törvény alapján adóköteles, így ennek megtartása a gazdasági kritériumnak való megfeleltetést garantálja. 2007-ben a gazdasági tevékenységek egységes ágazati osztályozási rendszere, azaz a TEÁOR a prostitúciós tevékenységet 96-os kódszámmal egyéb személyi szolgáltatás, azon belül 9604-es sorszámmal fizikai közérzetet javító szolgáltatásként bejegyezte. Az adóhatóság így egyéni vállalkozói igazolvány kiváltása, és adószám lajstromozása után a szolgáltatás folytatására az engedélyt megadni köteles. (A hatályos személyi jövedelemadóról szóló 1995. évi CXVII. törvény, valamint az egyéni vállalkozókról szóló 2009. évi CXV. törvényben e rendelkezések megtaláhatók.) Amennyiben tehát a prostituált a szolgáltatás megrendelését és teljesítését követően az elvégzett munkáról számlát nem állít ki, adózatlan, azaz illegális jövedelemre tesz szert. Ugyan így az is, aki ezt a beszerzett, illegális jövedelmet, mint hasznot lefölözi (például futtató). 314

A következő fejezetben tekintsük meg, hogy az ország GDP-jét, a prostitúcióból származó illegális jövedelmek a közelmúltban hogyan befolyásolták, milyen statisztikai módszerrel sikerült azt meghatározni, a nagyságát kiszámolni, annak behajtása a hatóságok tekintetében eredményes volt-e, ha igen, akkor mennyire. Mindehhez a bruttó nemzeti jövedelem számítása során a magyar gyakorlatban alkalmazott módszerek és

\footnotetext{
${ }^{312}$ KovÁCS István: Az üzletszerü kéjelgéssel kapcsolatos rendöri visszaélések etikai vonatkozásai. In. Belügyi Szemle, 2015/c/4. pp. 99-125.

${ }^{313}$ KovÁCs István: Prostitúció, és prohibíció a mai Magyarországon: avagy miért nem sikerül a rendörségnek a szocializmust levetközni a XXI. században. Létünk, 2018/2. p. 17.

314 KovÁCs István: Die kriminalpsychologischen Charakterzüge eines Zuhälters Aufgrund der antisozialen, psychopatischen, und soziopathischen Persönlichkeit. Hadtudományi Szemle, 2015/b/2. szám, pp. 150-161.
} 
adatforrások leírása (Inventory) a 1287/2003 Tanácsi Rendelet követelményei alapján készült módszertani leírás adott segítséget. ${ }^{315}$

\section{Prostitúció, mint illegális jövedelem a statisztika tükrében}

A KSH becslésen alapuló számításokat közöl a prostitúció bevételéről. Ez a módszertan hasonló a kábítószer kereskedelme során alkalmazottakhoz. A fogyasztás első számítása a fogyasztók száma és összetétele az igénybevétel formái szerint, az igénybevétel gyakorisága, a hazai termelés értéke, a jövedelemtulajdonosok összetétele, és az átlagos fogyasztói ár becslésével készült, amely a prostitúció vonatkozásában a témában készült tanulmányok, valamint érdekvédelmi szervezetek beszámolóival, és a rendörségi statisztikával is kiegészül. ${ }^{316}$ (Ugyanakkor megjegyzendő és elgondolkodtató, hogy, ha rangsorolnunk kellene e statisztikai adatbázisokat, mégiscsak a nyomozóhatósági, például az ENyÜBS, vagy a rendőrség hivatalos statisztikai adatbázisai foglalnának magukban kellő közhiteles mértékű regisztrált adatot, amelyek viszont nem becslésen, hanem akár elkövetői, akár sértetti oldalról, számszerüsítve tartalmazzák a prostitúció jelenségének holdudvari mérőszámait. Példának okáért ilyen adat a büntetőeljárások száma, a sértettek száma, kliensi kör, a szabálysértési nyilvántartási rendszer szükséges és arányos mértékben felhasznált rekordjai. ${ }^{317}$ Ugyanis, ha más -, akár az érdekvédelmi szervezetek, akár tanulmányok - a prostitúció jelenségéről regisztrált adatokkal rendelkeznének, akkor a New Yorki Egyezmény azon taktusait, amely tiltja a prostituáltak nyilvántartásban vételét, egyértelmüen sértenék. A nyomozóhatóságok mindezzel ellentétben a büntetőeljáráshoz, a szabálysértési eljáráshoz szükséges és arányos mértékig személyes adatot használhatnak fel, amely, ha ezt a kritériumot nem haladja meg, úgy nem keletkezik hatalmi visszaélés. ${ }^{318}$ Logikailag következik, hogy például a Szabálysértési Nyilvántartási Rendszer ilyen adatforrásnak tekinthetö-e, ha igen, akkor milyen mértékig. Mikor a rendör igazoltat, helyszíni bírságot szab ki, előállít, netán szabálysértési őrizetbe vételt foganatosít, vagy a bíróság elzárást rendel el, pénzbüntetést szab ki, azt nem egy személlyel, hanem mint rendszerben rögzített prostituálttal szemben alkalmazza.

A PHARE Exhaustivness projekt keretében a KSH próbaszámítást végzett az illegális tevékenységek két fő területének, nevezetesen a prostitúció és a kábítószer használat számszerüsítése érdekében. A számítás eredményei nem azonnal, hanem egy nagyobb módszertani felülvizsgálat részeként váltak a rendszeres kalkuláció részévé. ${ }^{319}$

315 GNI Inventory: Budapest, Központi Statisztikai Hivatal, 2009. Forrás: https://www.ksh.hu/docs/hun/xftp/modsz/gni_inventory_ver2.1hun.pdf) (A letöltés ideje: 2019.03.26.)

316 GNI Inventory: Budapest, Központi Statisztikai Hivatal, $2009 . \quad$ Forrás: https://www.ksh.hu/docs/hun/xftp/modsz/gni_inventory_ver2.1hun.pdf) (A letöltés ideje: 2019.03.26.)

317 KovÁCS István: Kiberbiztonság. Gyermekek szexuális kizsákmányolása az interneten, azaz gyermekpornográfia Magyarországon, különös tekintettel a nemzetközi iOCTA értékelésére. Rendvédelem, 2018/a/1. szám, pp. 178-267.

${ }^{318}$ KovÁCs István: A prostitúció jelensége és társadalmi kontrolljának vizsgálata empirikus módszerekkel. $\mathrm{PhD}$ értekezés, Budapest, UNI-NKE, 2016.

${ }^{319}$ A második világháború után Sztálin visszautasította a Marshall-tervben való részvételt. Ezt követôen a szovjet blokkal az együttmüködés egyetlen színtere a NATO maradt. Ezt követően a 80-as évektől Gorbacsov nevével fémjelzett új politikai irány két alapelve a peresztrojka (átalakítás) és a glasznoszty (nyitottság) volt, ami jelentős változást hozott a korábbi kommunista eszközökhöz - az erőszakhoz, a hazugsághoz és a titkolózáshoz - képest. Magyarországon különösen Kádár János halála után, egyre nyíltabban merült fel a liberalizáció iránti igény. A Párizsban megrendezett G7 találkozón az EK vezetői arról döntöttek, hogy pénzügyi és strukturális támogatást nyújtanak lengyelországi és magyarországi reformmozgalmaknak. Ennek eredményeként indult útjára a Phare program, teljes nevén a „Poland- 
Az elkövetkezendökben tekintsük meg, hogy mindezek alapján miként, és számszerủen milyen statisztikai adatokkal vált a prostitúció a GDP részévé.

\subsection{A prostitúcióval kapcsolatos fogyasztás nagysága}

A KSH a prostitúcióval kapcsolatos fogyasztás nagyságának meghatározásához a szexuális szolgáltatást vásárlók létszámát, a megvásárolt alkalmak mennyiségét és az igénybe vett szolgáltatások átlagárát vette alapul. A fő adatforrások voltak: orvosi és bírósági adatok, rendőrségi jelentések, adóhatósági GNI Inventory Hungary 265-s vámhatósági adatok, a prostituáltak érdekvédelmi szervezetének adatai és egyéb tanulmányok. A folyó termelőfelhasználás becslésére elsősorban a rendőrségi jelentéseket használták fel. Jól látható, hogy az adatbázis olyan adatokkal is kiegészül, mint az orvosi-, vagy a vámhatósági adatok. (Ennek jogpolitikai indoka egyértelmüen az egyéni vállalkozói igazolvány meglétének ellenőrzése, illetőleg az orvosi kiskönyv kiállítása.) A fentiek eredményeképpen a fogyasztás nagysága 111.004 millió forintban került megállapításra a millennium után. A fogyasztás nagyságának becsült értékét az alábbi grafikon foglalja össze.

1. grafikon: A prostitúció fogyasztásának nagysága (millió forintban) Forrás: a GNI Inventory alapján szerkesztette a szerzö

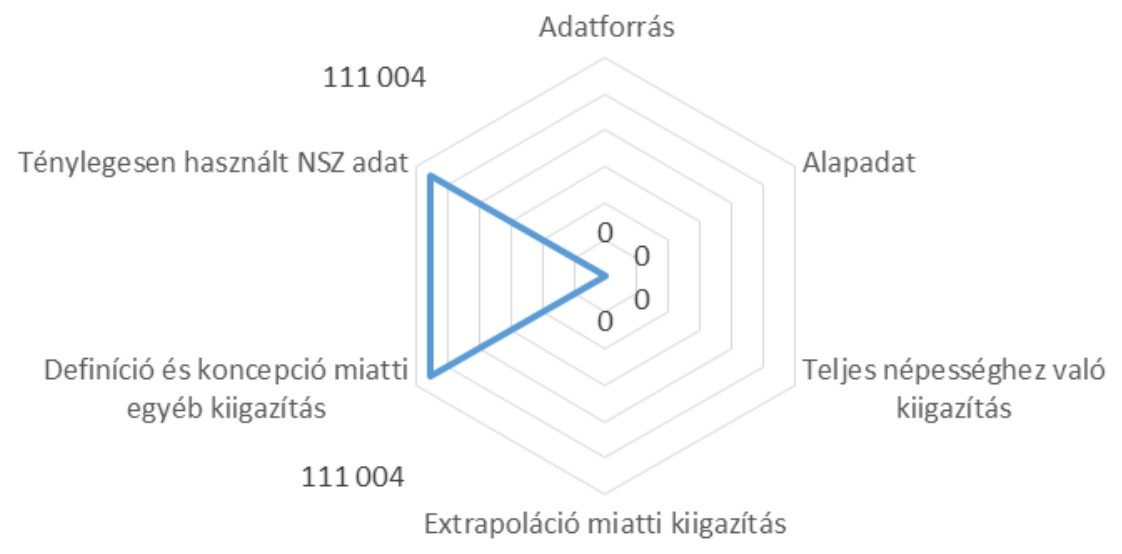

\subsection{A prostitúcióból származó fogyasztás becslése}

A KSH részére a szexuális szolgáltatásokat vásárlók körének meghatározása vonatkozásában elsősorban a prostituáltak érdekvédelmét szolgáló civil szervezetek és szociológiai jelentések nyújtanak információt. Ebből az derül ki, hogy a szexuális szolgáltatásokat vásárlók köre kétharmad részben külföldi. Ezt a Magyarországon áthaladó kamion-forgalomnak, és a turista jelenlétnek társítják. A hazai fogyasztók létszáma csak a peep-show müsorok, a szextelefon-müsorok, vagy az interneten elérhető pornográf filmek közönségében vannak többségben. A tanulmány és a szerző álláspontja szerint viszont - tiszteletben tartva e adatszolgáltatások legitimitását -a rendőrségi adatbázisok ennél jóval szélesebb, és egzaktabb adatokkal szolgálhatnak,

Hungary, Assistance for the Reconstruction of the Economy”, azaz a Lengyelország-Magyarország segélyprogram a gazdaság újjáépítésére. In: CzÁKA Sarolta (szerk.): Phare korszak Magyarországon. Falu, város, régió. 2007/1. szám, pp. 1-90. 
amely a becslések eredményeit módosíthatják. Példának okáért, ha vizsgálat tárgyát képezné a tiltott prostitúció gyakorlásán tettenért intézkedések adatai, úgy az ügyfelek e meghatározásra irányadó rekordjairól is pontos képet kaphatnánk.

A szexuális szolgáltatások során megvásárolt alkalmak éves számát mindezek mellett a szexuális vásárlásokat igénybevevők körének és a vásárlási gyakoriság számából sikerült a KSH-nak meghatározni.

A prostituáltak létszáma és összetétele a jelenség legnehezebben meghatározható és körüljárható eleme. Részben a New York-i Egyezmény, részben a hazai kodifikáció eredménye, hogy a prostituáltakról regisztrált nyilvántartás nem vezethető, illetőleg számos más objektív körülmény - egyéni vállalkozói igazolvány hiánya, hiányos adatszolgáltatások, a prostitúció gyakorlásának ad hoc jellege, stb. - hátráltatja ennek meghatározhatóságát. Ugyanakkor részeredményeket a fentebb ismertetett módszerek nyújthatnak, de az tényleg csak részszegmense az előttünk egyáltalán nem ismert tevékenységi létszámnak.

A fogyasztói alkalmak átlagos ára - attól függően, hogy milyen körülmények között történt a szolgáltatás igénybevétele - nagyon differenciált. A legolcsóbb út menti szolgáltatáshoz viszonyítva mintegy másfélszer annyi a lakásban végzett-, kétszer annyi a vendéglátóhelyen igénybe vett, és háromszor annyi a szállodákban vásárolt szolgáltatások átlagára.

A KSH észrevételei között szerepel, hogy a szexuális szolgáltatásokat nyújtó vállalkozások egy része formálisan nem az illegális gazdaság része - csak gyakorlatilag az. Számtalan szolgáltatásról lehet úgy számlát kiállítani, hogy e mögött a tevékenység mögött valójában szexuális szolgáltatás áll. Jól jár a szolgáltató is, mert formálisan legális üzletvitel mögött végzi a szexuális szolgáltatást, és jól jár a vásárló is, mert nem az adózott jövedelméből kell kifizetnie a szexuális szolgáltatás árát. Utal ezzel a KSH azokra a masszázs-szalonként, vagy éjszakai bárként funkcionáló, valójában viszont illegális bordélyként müködő hálózatokra, amelynek létesítését a hatályos Büntető Törvénykönyv, valamint a millenniumi években hatályban levő Büntetö Törvénykönyv (1978. évi IV. törvény) is büntetni rendelte. (Azt, hogy a futtatók ezt hogyan próbálták meg kijátszani egy korábbi tanulmányom részleteiben elemzi. $)^{320}$

A fentiek függvényében megállapítható, hogy összesen hazai és külföldi vonatkozásban 131698 millió forint volt a prostitúció fogyasztásának becsült értéke, amelyből mindösszesen 20694 millió forint került elszámolásra a millenniumi években. A teljes adathalmazt a forrás tartalmazza, annak szerkesztett részeredményeit az alábbi táblázat szemlélteti.

1. táblázat: A prostitúció fogyasztásának becslése

Forrás: a GNI Inventory alapján szerkesztette a szerzö

\begin{tabular}{|c|c|c|c|c|c|c|c|c|c|c|c|}
\hline \multirow[t]{4}{*}{$\begin{array}{l}\text { A szolgáltatás } \\
\text { körülményei }\end{array}$} & \multicolumn{2}{|c|}{ Fogyasztók } & \multicolumn{2}{|c|}{$\begin{array}{c}\text { Fogyasztói } \\
\text { alkalmak }\end{array}$} & \multicolumn{2}{|c|}{$\begin{array}{c}\text { Fogyasztói } \\
\text { alkalmak }\end{array}$} & Átlagár & \multicolumn{4}{|c|}{ FOGYASZTÁS } \\
\hline & \multirow{2}{*}{\multicolumn{2}{|c|}{1000 fö }} & \multirow{2}{*}{\multicolumn{2}{|c|}{ havi átlag }} & \multirow{2}{*}{\multicolumn{2}{|c|}{$\begin{array}{c}\text { év összesen, } \\
\text { ezer }\end{array}$}} & \multirow{3}{*}{ ezer Ft } & \multicolumn{4}{|c|}{ folyó áron, millió Ft } \\
\hline & & & & & & & & & & & ebböl \\
\hline & hazai & külföldi & hazai & külföldi & hazai & külföldi & & hazai & külföldi & Összesen & már elszámolt \\
\hline Országút, utca & 132 & 66 & 2,0 & 1,0 & 3168 & 792 & 4 & 12672 & 3168 & 15840 & 3520 \\
\hline Lakás & 60 & 30 & 2,0 & 1,0 & 1440 & 360 & 5 & 7200 & 1800 & 9000 & 996 \\
\hline További adatok... & & & & & & & & & & & \\
\hline Összesen & & & & & & & & 94939 & 36758 & 131698 & 20694 \\
\hline
\end{tabular}

${ }^{320}$ KovÁCs István: „Olajozás”, szervezett bünözés és prostitúció a 90-es években Magyarországon. Nemzetbiztonsági Szemle, 2015/a/1. szám, pp. 114-145. 


\subsection{A prostitúcióból származó jövedelmek becslése}

A KSH számításai szerint a prostitúcióból eredő bevételek nem azonosak az ilyen tevékenységből származó jövedelmekkel. A szexuális szolgáltatások bevételeinek mintegy harmada a szolgáltatással összefüggő termelési költségek fedezését szolgálja. Ezekbe a termelési kiadásokba nem értendők bele azok a szintén rejtett jövedelmi tételek, amelyek ugyan a prostituált szemszögéből termelési kiadások, de a GDP számítás szemszögéből a prostitúció, mint üzleti vállalkozás eredeti jövedelmei. ${ }^{321}$ Ezek a bevételi források, amelyeket a prostituáltaktól a futtatók elvesznek, vagy ők leadni kötelesek. (E statisztikai adat is differenciáltságot tükröz, hisz van olyan prostituált, akitől a futtató az egész-, van, akitől egy részét veszi el, azonban igaz, hogy elhanyagolható számban, de egyedüli munkavégzésre is van lehetőség. Ezen adat kiegészül a közvetítői jutalékokkal is.) ${ }^{322}$ Jól látható, hogy összesen importértékként 131698 millió forint értékeben történt e szolgáltatás terén kibocsátás.

2. táblázat: A prostitúcióból származó jövedelem becslése Forrás: a GNI Inventory alapján szerkesztette a szerző

\begin{tabular}{|c|c|c|c|c|}
\hline $\begin{array}{l}\text { A szolgáltatás } \\
\text { körülményei }\end{array}$ & $\begin{array}{l}\text { Import } \\
\text { értéke }\end{array}$ & $\begin{array}{c}\text { Folyó } \\
\text { termelőfelhasználás }\end{array}$ & $\begin{array}{l}\text { Hozzáadott } \\
\text { érték }\end{array}$ & Kibocsátás \\
\hline & $a$ & $\mathrm{~b}$ & $\mathrm{c}$ & $a+b+c$ \\
\hline Országút, utca & 1404 & 3520 & 10916 & 15840 \\
\hline Lakás & 324 & 996 & 7680 & 9000 \\
\hline \multicolumn{5}{|l|}{ Többi adat... } \\
\hline ÖSSZESEN & 11545 & 20694 & 99459 & 131698 \\
\hline
\end{tabular}

\subsection{Aruk és szolgáltatások importja és exportja}

A számítások vonatkozásában akárcsak a prostitúcióval kapcsolatos fogyasztás nagyságához az alapadatokat a szexuális szolgáltatást vásárlók létszáma, a megvásárolt alkalmak mennyisége és az igénybe vett szolgáltatások átlagára adta. Az adatforrások tekintetében változás szintén nem volt. A fentiekkel összefüggésben megállapítható volt, hogy export szintjén 42600 millió forint mennyiségü a prostitúciós szolgáltatás nagysága, import vonatkozásában ez nullás értéket generált. Mindezt a KSH arra alapozta, hogy a rendelkezésre álló adatok szerint a külföldön dolgozó magyar, valamint a Magyarországon munkát vállaló külföldi prostituáltak száma majdnem megegyezik. A prostitúciós szolgáltatás exportja és importja az alábbi grafikonon szemléltethető.

321 GNI Inventory: Budapest, Központi Statisztikai Hivatal, 2009. Forrás: https://www.ksh.hu/docs/hun/xftp/modsz/gni_inventory_ver2.1hun.pdf) (A letöltés ideje: 2019.03.26.)

${ }^{322}$ KovÁCs István: A prostitúció jelensége és társadalmi kontrolljának vizsgálata empirikus módszerekkel. $\mathrm{PhD}$ értekezés, Budapest, UNI-NKE, 2016. 


\section{2. grafikon: A prostitúció szolgáltatás importja és exportja (millió forintban) Forrás: a GNI Inventory alapján szerkesztette a szerzö}

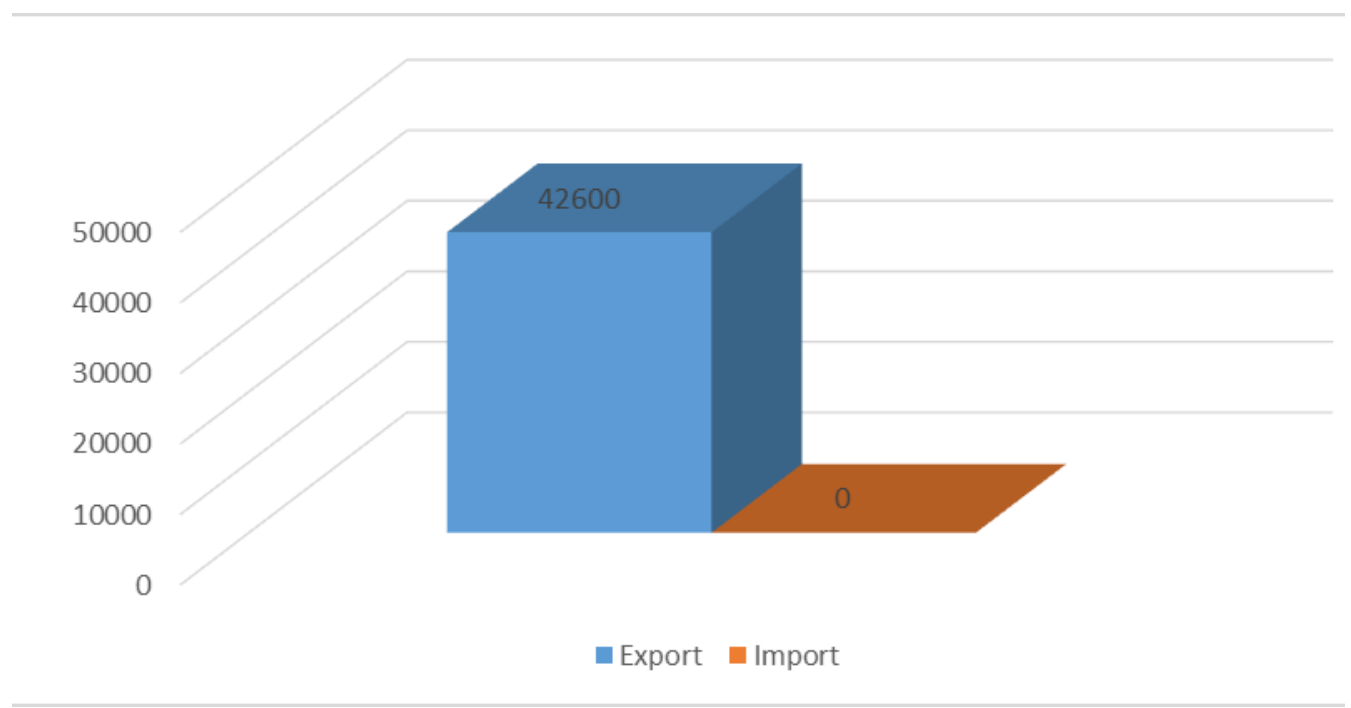

\section{4. Összegzés és javaslatok}

Egy demokratikus társadalom müködésének feltétele, hogy azonos joggyakorlás, és azonos kötelemteljesítés vonatkozik a társadalomban élőkre. Nincs mentség a tekintetben, hogy, ha az állam megteremti a prostitúció legális gyakorlásának feltételeit, akkor annak maradéktalan betartására a prostituáltakat ne kötelezze, annak hiánya esetén pedig őket ne szankcionálja. Ugyanakkor nem szabad elfeledkeznünk arról, hogy Magyarországon -, pont a nemzetközi egyezménnyel való diszharmonizációnak köszönhetően - milyen jogi, társadalmi anomáliákba, és ezzel együtt többszörösen a 22-es csapdájába esünk.

Ahogy azt a tanulmány is részleteiben taglalja e illegális bevételek nagyrésze vagy teljes egésze nem a prostituáltak, hanem a prostitúció holdudvarának kezébe kerül. Nagyobb hangsúlyt szükséges fekteti arra, hogy a futtatói hálózatok felderítése és elfogása megtörténjen, és azok a milliárdos illegális bevételek ne a szervezett bünözői köröket, hanem az állami büdzsét gyarapítsák.

Ha elvárjuk a prostituáltaktól, hogy egyéni vállalkozói igazolványt váltsanak ki, és minden egyes szolgáltatás után adót fizessenek, úgy elsőként biztosítani kell számukra, hogy azt az önkormányzat által kijelölt munkavégzéshez helyszínen hajthassák végre. Azzal, hogy a munkavégzés helyszínéül védett övezeten kívüli terület kijelölésre nem kerül, egy olyan jogellenes spirált hozunk létre, amelynek végeredménye, hogy a prostituáltak hiába törekednek jogszerü munkavégzésre, az egyébként jogszerü magatartás is jogellenessé fordul, és szankcionálhatóvá válik. (Nincs ez másképpen a www.rosszlanyok.hu, vagy a https://beszamolok.com/szexpartner oldalakkal sem, azon szexmunkások esetében, akik ingatlanokban dolgoznak.) Ha nincs kötelezettségteljesítés az állam oldalán, akkor nem várható el a legális joggyakorlás sem a prostituáltak oldaláról.

A szankcionálással összefüggésben el kell gondolkodnunk azon, hogy, ha mindez a jövedelem valóban illegális, akkor hogyan tudnánk a kiszabott pénzbüntetést behajtani? (Ugyan ez a helyzet a helyszíni bírság kiszabásával is.) Ha nem dolgozik a jogalany, akkor miből fizeti ki a kiszabott szankciót? Megtérül az állam jövedelme, ha mindezt elzárásra váltjuk át? Nem keletkezik mínusz az állam oldalán, ha az elzárás 
napi díját (ellátás, stb.) is neki kell kigazdálkodnia? Ehhez kapcsolódóan érdemes elgondolkodnunk azon is, hogy az elzárásnak konjuktív feltételei vannak, bármelyik hiánya esetén az, mint kényszerintézkedés nem alkalmazható, így a hiányzó adóbevétel szintén nem hajtható be. Milyen intézkedés szükséges ahhoz, és egyben alkalmas arra, hogy e jövedelmet az állam megtakaríthassa?!

Álláspontom szerint megoldás kizárólag az emberi és alkotmányos alapjogok

gyakorlásán nyugvó, új rendvédelmi szabályozással biztosított, és jogszabálymódosítással alkotott állami bordélyrendszeri müködtetése jelentené. $\mathrm{E}$ rendszer kiépítése és megalakítása nem veti fel a teljes New York-i Egyezmény felbontását, annak csupán egy részét szükséges felmondanunk, amely a bordélyrendszer kiépítésére és a nyilvántartó tevékenységet érinti. Miért? Elgondolkodtatásra késztet, hogy, ha a futtatók nem vennék el részben vagy teljes egészben a prostituáltak jövedelmét, akkor vajon ugyan így illegalitásba burkolódzna-e a jelenség, és ugyan így elmulasztanák-e a szexmunkások az adó befizetését? A biztosított munkahely részünkre rendelkezésre állna. A regisztrációval pedig prevencionálhatnánk a fiatalkorúak prostitúcióját, illetőleg nem becslésen, hanem egzakt számadatokon alapuló képet kaphatnánk annak kiterjedéséről és milyenségéről. (Más különleges szakértelmet igénylő szakmákban dolgozó személyke is regisztrálásra kerülnek. A prostitúció pedig gyakorolható munka. Ha a társadalom egy része nem elöítélettel tekintene a XXI. században arra, akkor talán e sztereotíp gondolkodás nem vetné fel a stigmatizáció kérdéskörét.)

Mindazonáltal a témában született tudományos munkák hozzásegíthetnek ahhoz, hogy a XXI. század hajnalán a közel két évezrede tartó társadalmi vita végére pontot tegyünk, és korunkat meghazudtolva paradigmaváltó gondolkodásunk eredményeként, a jelenség szabályozását új mederbe engedjük.

\section{Felhasznált irodalom}

[1] CzÁKA Sarolta (szerk.): Phare korszak Magyarországon. Falu, város, régió. 2007/1. szám, pp. 1-90.

[2] GNI INVENTORY. Budapest, Központi Statisztikai Hivatal, 2009. Forrás: https://www.ksh.hu/docs/hun/xftp/modsz/gni_inventory_ver2.1hun.pdf) (A letöltés ideje: 2019.03.26.)

[3] HAVOSCOPE: Prostitution: Prices and Statistics of the Global Sex Trade. Forrás: https://www.amazon.com/dp/B00ZZBFXO2/ref=rdr_kindle_ext_tmb (A letöltés dátuma: 2017.04.17.)

[4] JANÁK Katalin (szerk.): Mikrocenzus 2016. A foglalkozások presztízse. Budapest, Központi Statisztikai Hivatal, 2018.

[5] KovÁCs István: „Olajozás”, szervezett bünözés és prostitúció a 90-es években Magyarországon. Nemzetbiztonsági Szemle, 2015/a/1. szám, pp. 114-145.

[6] KovÁCs István: A prostitúció jelensége és társadalmi kontrolljának vizsgálata empirikus módszerekkel.PhD értekezés, Budapest, UNI-NKE, 2016.

[7] KovÁCs István: A szervezett bünözés két alappillére: az emberkereskedelemhez kapcsolódó prostitúciós büncselekmények valamint a kábitószer-kereskedelem összefonódása. Nemzetbiztonsági Szemle, 2014., II. évfolyam 4. szám, pp. 79101.

[8] KovÁCs István: Az üzletszerü kéjelgéssel kapcsolatos rendöri visszaélések etikai vonatkozásai. In. Belügyi Szemle, 2015/c/4. pp. 99-125. 
[9] KovÁCs István: Die kriminalpsychologischen Charakterzüge eines Zuhälters Aufgrund der antisozialen, psychopatischen, und soziopathischen Persönlichkeit. Hadtudományi Szemle, 2015/b/2. szám, pp. 150-161.

[10] KovÁCS István: Is the prostitution a threat/danger to a country's (national)security? Nemzetbiztonsági Szemle, 2017/d/Special Issue, pp. 1-24.

[11] KovÁcs István: Jogharmonizáció vagy sem? Első rész: a New Yorki Egyezmény és a 2012. évi C. törvény - a Büntetö Törvénykönyv -. Jogelméleti Szemle, 2017/a/2. szám, pp. 88-106.

[12] KovÁCs István: Jogharmonizáció vagy sem? Harmadik rész: a New Yorki Egyezmény és a 13/2014. (V.16) ORFK utasitás. Belügyi Szemle, 2017/c/10. szám, pp. 42-59.

[13] KovÁCS István: Jogharmonizáció vagy sem? Második rész: a New Yorki Egyezmény, valamint a 2012. évi II.-, és a 1999. évi LXXV. törvény. Acta Humana, 2017/b/5. szám, pp. 41-58.

[14] KovÁCs István: Kiberbiztonság Gyermekek szexuális kizsákmányolása az interneten, azaz gyermekpornográfia Magyarországon, különös tekintettel a nemzetközi iOCTA értékelésére. Rendvédelem, 2018/a/1. szám, pp. 178-267.

[15] KovÁCs István: Magyarország határain átnyúló szervezett bünözés és prostitúciós büncselekmények a schengeni térségben, különös tekintettel a SOCTA és EUROSTAT értékelésére. Határrendészeti Tanulmányok, 2017/e/4. szám, pp. 82-161.

[16] Kovács István: Pornográfia, vagy prostitúció, esetleg mindkettő? Hadtudományi Szemle, 2017/f/4. szám, pp. 449-484.

[17] KovÁcs István: Prostitúció, és prohibíció a mai Magyarországon: avagy miért nem sikerül a rendörségnek a szocializmust levetkőzni a XXI. században. Létünk, 2018/b/2. p. 17.

Lektorálta: Deák József Dr. PhD. tanársegéd Nemzeti Közszolgálati Egyetem Rendészettudományi Kar Rendészettörténeti Tanszék deak.jozsef@uni-nke.hu 